\title{
Estrogen Receptor $\alpha$ Regulates Ethanol Excitation of Ventral Tegmental Area Neurons and Binge Drinking in Female Mice
}

\author{
Bertha J. Vandegrift, ${ }^{1,2}$ Elisa R. Hilderbrand, ${ }^{1}$ Rosalba Satta, ${ }^{1}$ Rex Tai, ${ }^{1}$ Donghong He, ${ }^{1}$ Chang You, ${ }^{2}$ Hu Chen, ${ }^{1}$ \\ Pingwen Xu, ${ }^{3}$ Cassandre Coles, ${ }^{1}$ Mark S. Brodie,,${ }^{1,2}$ and ${ }^{\circledR}$ Amy W. Lasek ${ }^{1}$ \\ ${ }^{1}$ Center for Alcohol Research in Epigenetics and Department of Psychiatry, ${ }^{2}$ Department of Physiology and Biophysics, and ${ }^{3}$ Department of \\ Medicine, Division of Endocrinology, Diabetes and Metabolism, University of Illinois at Chicago, Chicago, Illinois 60612
}

Elevations in estrogen (17 $\beta$-estradiol, E2) are associated with increased alcohol drinking by women and experimentally in rodents. E2 alters the activity of the dopamine system, including the VTA and its projection targets, which plays an important role in binge drinking. A previous study demonstrated that, during high E2 states, VTA neurons in female mice are more sensitive to ethanol excitation. However, the mechanisms responsible for the ability of E2 to enhance ethanol sensitivity of VTA neurons have not been investigated. In this study, we used selective agonists and antagonists to examine the role of ER subtypes (ER $\alpha$ and $E R \beta)$ in regulating the ethanol sensitivity of VTA neurons in female mice and found that $\mathrm{ER} \alpha$ promotes the enhanced ethanol response of VTA neurons. We also demonstrated that enhancement of ethanol excitation requires the activity of the metabotropic glutamate receptor, mGluR1, which is known to couple with $\operatorname{ER} \alpha$ at the plasma membrane. To investigate the behavioral relevance of these findings, we administered lentivirusexpressing short hairpin RNAs targeting either ER $\alpha$ or ER $\beta$ into the VTA and found that knockdown of each receptor in the VTA reduced binge-like ethanol drinking in female, but not male, mice. Reducing ER $\alpha$ in the VTA had a more dramatic effect on binge-like drinking than reducing ER $\beta$, consistent with the ability of ER $\alpha$ to alter ethanol sensitivity of VTA neurons. These results provide important insight into sex-specific mechanisms that drive excessive alcohol drinking.

Key words: alcohol; dopamine; estrogen; estrogen receptors; sex differences

Significance Statement

Estrogen has potent effects on the dopamine system and increases the vulnerability of females to develop addiction to substances, such as alcohol. We investigated the mechanisms by which estrogen increases the response of neurons in the VTA to ethanol. We found that activation of the ER $\alpha$ increased the ethanol-induced excitation of VTA neurons. $17 \beta$-Estradiol-mediated enhancement of ethanol-induced excitation required the metabotropic glutamate receptor mGluR1. We also demonstrated that ERs in the VTA regulate binge-like alcohol drinking by female, but not male, mice. The influence of ERs on binge drinking in female mice suggests that treatments for alcohol use disorder in women may need to account for this sex difference.

Received Oct. 2, 2019; revised Mar. 25, 2020; accepted Apr. 22, 2020.

Author contributions: B.J.V., E.R.H., R.S., P.X., M.S.B., and A.W.L. designed research; B.J.V., E.R.H., R.S., R.T., D.H., C.Y., H.C., C.C., and M.S.B. performed research; B.J.V., E.R.H., R.S., R.T., D.H., H.C., C.C., M.S.B., and A.W.L. analyzed data; B.J.V. and E.R.H. wrote the first draft of the paper; E.R.H., R.S., P.X., and M.S.B. edited the paper; P.X. contributed unpublished reagents/analytic tools; A.W.L. wrote the paper.

This work was supported by National Institute on Alcohol Abuse and Alcoholism Grant P50 AA022538 to A.W.L. and M.S.B. and Grant U01 AA020912 to A.W.L., National Institute on Drug Abuse Grant R01 DA033429 to A.W.L., and National Center for Advancing Translational Sciences Grant UL1TR002003. We thank Lucas Ibrahimi for mouse breeding and genotyping.

The authors declare no competing financial interests.

Correspondence should be addressed to Amy W. Lasek at alasek@uic.edu.

https://doi.org/10.1523/JNEUROSCI.2364-19.2020

Copyright $\odot 2020$ the authors

\section{Introduction}

Binge drinking is defined by the National Institute on Alcohol Abuse and Alcoholism as consuming enough alcohol within a 2 $\mathrm{h}$ period to reach a blood ethanol concentration (BEC) of at least $0.08 \%$. Binge drinking accounts for more than half of the deaths and three-fourths of the economic costs associated with excessive drinking (Stahre et al., 2014; Sacks et al., 2015). Women are more susceptible than men to the devastating health effects associated with alcohol abuse, including liver disease, cardiomyopathy, brain damage, and heightened risk for breast cancer (Agabio et al., 2016; White et al., 2017; Szabo, 2018). Women who binge drink also report having more physically and mentally poor days 
compared with male binge drinkers (Wen et al., 2012). Unfortunately, more women are drinking excessively now compared with previous decades (Grant et al., 2017). The biological factors that contribute to binge drinking by women are not well understood, although ovarian hormones, specifically estrogen (17 $\beta$-estradiol [E2]), may play a role. Circulating E2 levels in women are positively associated with alcohol consumption (Muti et al., 1998; Martin et al., 1999; Martel et al., 2017), and numerous alcohol drinking studies in female rodents have demonstrated that E2 administration increases alcohol drinking (Ford et al., 2002a, 2004; Marinelli et al., 2003; Reid et al., 2003; Quirarte et al., 2007; Rajasingh et al., 2007; Satta et al., 2018a). Understanding the molecular and cellular mechanisms of action of E2 in enhancing ethanol drinking is important for developing new approaches to reduce excessive drinking by women.

The mesocorticolimbic dopamine (DA) system is critical for the rewarding and reinforcing effects of ethanol (Gonzales et al., 2004; Lovinger and Alvarez, 2017). E2 has potent modulatory effects on this system (Yoest et al., 2018a). For example, E2 enhances cocaine-, amphetamine-, and potassium-stimulated DA release in the striatum of rats and mice (Becker, 1990a,b; Thompson and Moss, 1994; Tobiansky et al., 2016; Yoest et al., 2018b), and potentiates ethanol-stimulated DA release in the PFC of female rats (Dazzi et al., 2007). In accord with this finding, ethanol-induced excitation of VTA neurons in female mice is augmented when E2 levels are elevated (Vandegrift et al., 2017). However, the specific estrogen receptor(s) (ERs) that mediate(s) the enhancement of ethanol-stimulated firing of VTA neurons is/are currently not known.

The first goal of this study was to determine whether $\operatorname{ER} \alpha$ or $\mathrm{ER} \beta$ is responsible for the effect of E2 on the response of VTA neurons to ethanol. We used selective agonists and antagonists to $\mathrm{ER} \alpha$ and $\mathrm{ER} \beta$ combined with extracellular recordings of VTA neurons. Because membrane-bound ERs can rapidly activate cell signaling pathways through interactions with metabotropic glutamate receptors (mGluRs) and affect neurotransmission and behavior (Tonn Eisinger et al., 2018), the second goal of this study was to determine whether the enhancement of ethanol-stimulated VTA neuron firing by E2 is dependent on mGluR1 activity.

The third goal of this study was to examine the potential relevance of ERs expressed in the VTA on alcohol drinking. We used virus-expressed short hairpin (sh)RNAs to reduce the expression of $\mathrm{ER} \alpha$ or $\mathrm{ER} \beta$ in the mouse VTA and measured binge ethanol drinking. Together, the results from our behavioral and electrophysiological experiments indicate that $\operatorname{ER} \alpha$ activation in the VTA enhances both ethanol-stimulated firing of VTA neurons and binge drinking in female mice. These studies provide important mechanistic and behavioral insights into ER signaling in the brain that are relevant to alcohol use disorder in females.

\section{Materials and Methods}

Animals. Female C57BL/6J mice were purchased from The Jackson Laboratory at the age of 8 weeks and used for immunohistochemistry (IHC), electrophysiology, and behavioral experiments at the age of 1014 weeks. Male C57BL/6J mice were also purchased from The Jackson Laboratory at the age of 8 weeks and used for behavioral experiments at the age of 10-14 weeks. Transgenic mice containing a bacterial artificial chromosome-expressing EGFP under the control of the Esr2 promoter were obtained from the Mutant Mouse Regional Resource Center at the University of California, Davis (strain B6.FVB(Cg)-Tg(Esr2-EGFP) ID169Gsat/TmilMmucd, stock \#036904-UCD) (Milner et al., 2010) and were used as a reporter for $\operatorname{ER} \beta$ expression in IHC experiments due to a lack of commercially available antibodies specific for mouse $\operatorname{ER} \beta$ (Snyder et al., 2010). Mice containing a floxed Esr1 (Esr1 fl/fl) allele in which exon 3 is flanked by loxP sites were originally obtained from Sohaib A. Khan and have been backcrossed to C57BL/6J for 12 generations (Feng et al., 2007). Mice were bred at University of Illinois at Chicago, and homozygous offspring ranged in age from 3 to 6 months at the time of electrophysiology experiments. Mice were housed in groups of 3-5 in a temperature- and humidity-controlled room with a $12 \mathrm{~h}$ light/dark cycle (lights on at 6:00 A.M.), with food and water available ad libitum, except water was not available during the limited-access ethanol drinking tests described below. Animal care adhered to the National Institutes of Health's Guide for the care and use of laboratory animals, and all procedures were approved by the University of Illinois at Chicago Animal Care Committee.

Vaginal cytology. The estrous cycles of gonadally intact female mice were assessed by vaginal cytology for at least 2 weeks before performing experiments, as previously described (Vandegrift et al., 2017). Briefly, a cotton swab was moistened with sterile water and gently rotated at the vaginal opening. The swab was wiped on a microscope slide, and the smear was immediately analyzed by bright field microscopy using an EVOS FL inverted microscope (Thermo Fisher Scientific). Estrus was identified by a large quantity of cornified epithelial cells, whereas diestrus was determined by a predominance of leukocytes (Nelson et al., 1982). These two phases differ in circulating E2 levels. Serum E2 levels in mouse are higher during late diestrus (diestrus II) than estrus and are not statistically significantly different from levels during proestrus as measured by gas chromatography-tandem mass spectrometry (Nilsson et al., 2015).

Fluorescent IHC. Mice were killed using a lethal dose of a commercial euthanasia solution containing pentobarbital (Somnasol) and transcardially perfused with ice-cold PBS, followed by $4 \%$ PFA. Brains were removed and postfixed in PFA overnight and cryoprotected in 30\% sucrose. Serial coronal sections $(40-\mu \mathrm{m}$-thick) were collected through the VTA. Sections were blocked in 5\% normal donkey serum (Jackson ImmunoResearch Laboratories, \#017-000-121, RRID:AB_2337258) and then incubated with various combinations of the following primary antibodies: $\mathrm{ER} \alpha$, rabbit polyclonal, Sigma Millipore, \#06-935, RRID:AB_310305; GFP, mouse monoclonal 3E6, Thermo Fisher Scientific, \#A-11120, RRID:AB_221568; TH, mouse monoclonal LNC1, Sigma Millipore, \#MAB318, RRID:AB 827536; TH, rabbit polyclonal, Sigma Millipore, \#AB152, RRID:AB_ 390204; Cre recombinase, rabbit monoclonal, Cell Signaling Technology, \#15036, RRID:AB_2799373. Secondary antibodies were AlexaFluor-594conjugated donkey anti-rabbit (Jackson ImmunoResearch Laboratories, \#711-585-152, RRID:AB_2340621) and AlexaFluor-488-conjugated donkey anti-mouse (Jackson ImmunoResearch Laboratories, \#715-545-150, RRID:AB_2340846). Sections were mounted onto slides with Vectashield mounting medium (Vector Laboratories). Images in Figures 1 and 3 were acquired with an LSM 710 laser scanning confocal microscope using a $40 \times$ objective (Carl Zeiss; all mice were in estrus). Images from Figure 6 were acquired using an EVOS FL microscope (Thermo Fisher Scientific) using a $4 \times$ objective. ImageJ software (National Institutes of Health) was used for quantification of $\mathrm{ER} \alpha$ expression in $\mathrm{TH}$-expressing cells in mice injected with adeno-associated virus-9 (AAV9) in the VTA. Images were obtained from 2 sections per mouse, and density of $\mathrm{ER} \alpha$ immunoreactivity was obtained from 8 TH-positive cells/mouse. Average ER $\alpha$ density was calculated from these 8 cells/mouse, and this value was used as an individual data point ( $n=6$ mice per group).

Ovariectomy $(O V X)$. Mice were anesthetized with intraperitoneal injections of ketamine $(100 \mathrm{mg} / \mathrm{kg})$ and xylazine $(8 \mathrm{mg} / \mathrm{kg})$. Hair on the dorsal flanks was trimmed using a hair trimmer, and the skin was disinfected using 70\% isopropanol wipes. Bilateral incisions were made in the skin, and a small hole was teased in the muscle wall to allow access to the abdomen. The ovaries and associated fat pads were dissected away from the uterine horns. The muscle wall was sutured, and the skin was closed with wound clips. Mice received a subcutaneous injection of $2 \mathrm{mg} / \mathrm{kg}$ meloxicam immediately after surgery and once on the following day for analgesia. Cessation of the estrous cycle was verified by obtaining vaginal smears for a few days after OVX. Mice recovered for 2 weeks before beginning drug treatments. 

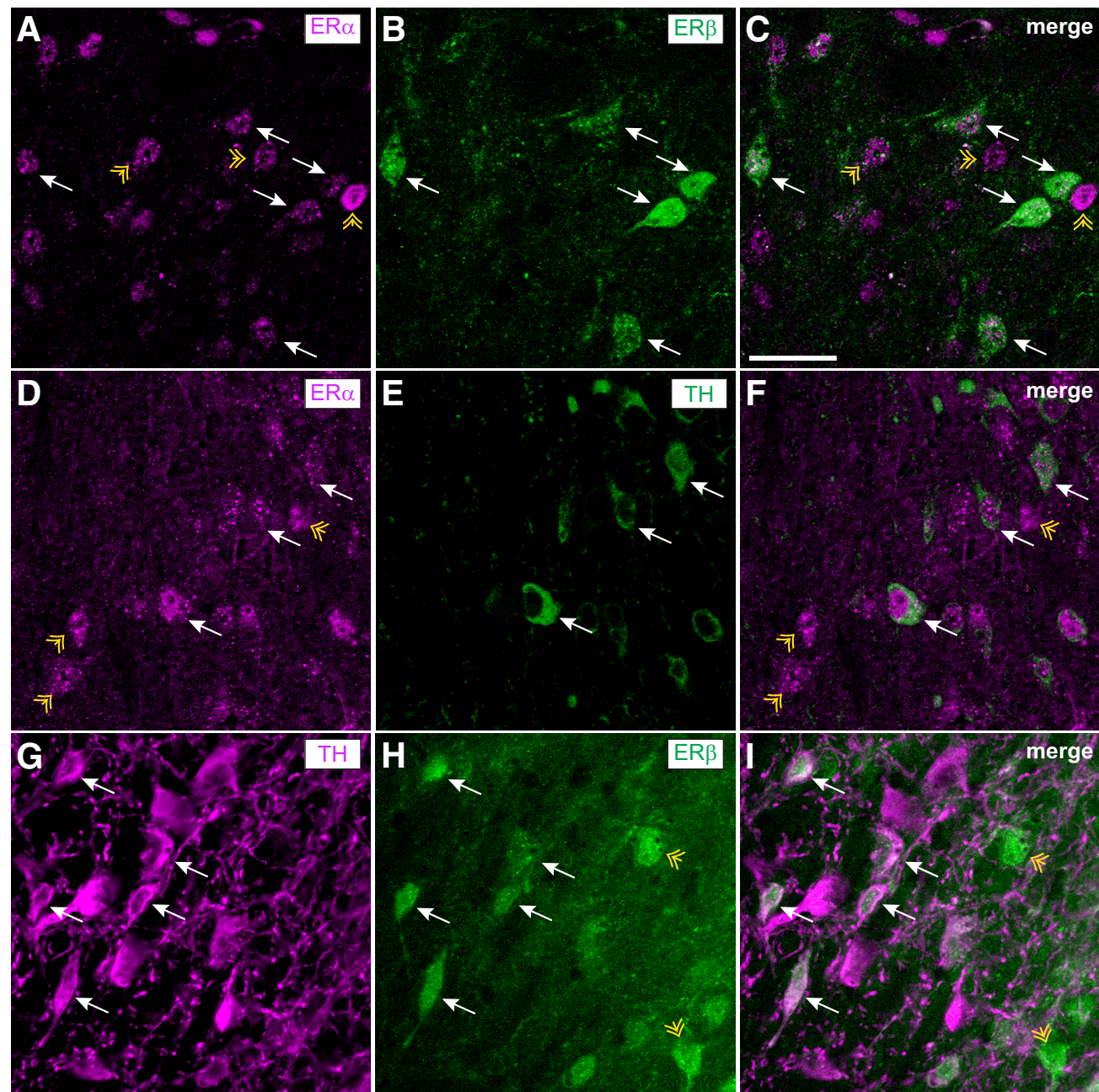

Figure 1. $\operatorname{ER} \alpha$ and $\operatorname{ER} \beta$ are expressed in DA neurons and nondopaminergic cells in the VTA. Brain sections containing the VTA from female mice in estrus were processed for fluorescent IHC with antibodies to ER $\alpha$, GFP (reporter for ER $\beta$ expression), and TH. A-C, Representative images showing ER $\alpha$ (magenta) and GFP (green) colocalization in the VTA of an ER $\beta$-GFP reporter mouse. White arrows indicate examples of ER $\alpha^{+} / \mathrm{GFP}^{+}$cells. Yellow arrowheads indicate examples of ER $\alpha^{+} / \mathrm{GFP}^{-}$cells. D-F, Representative images showing ER $\alpha$ (magenta) and TH (green) colocalization in the VTA of a C57BL/6J mouse. White arrows indicate examples of ER $\alpha^{+} / \mathrm{TH}^{+}$cells. Yellow arrowheads indicate examples of ER $\alpha^{+} / \mathrm{TH}^{-}$cells. $\mathbf{G}-I$, Representative images of TH (magenta) and GFP (green) colocalization in the VTA of an ER $\beta$-GFP reporter mouse. White arrows indicate examples of $\mathrm{TH}^{+} / \mathrm{GFP}^{+}$cells. Yellow arrows indicate examples of TH$/ \mathrm{GFP}^{+}$ cells. Scale bar, $50 \mu \mathrm{m}$.

In vivo drug treatments. Diarylpropionitrile (DPN, selective ER $\beta$ agonist, Tocris Bioscience), 4,4' $4^{\prime \prime}$-(4-propyl-[1H]-pyrazole-1,3,5-triyl)trisphenol (PPT, selective $\mathrm{ER} \alpha$ agonist, Tocris Bioscience), and E2-3-benzoate, herein referred to as E2 (Sigma Millipore), were prepared in solutions of 90\% sesame oil/10\% ethanol (VEH). DPN and PPT were prepared to final concentrations of $0.5 \mathrm{mg} / \mathrm{ml}$. Mice were injected subcutaneously with $\sim 1 \mathrm{mg} / \mathrm{kg}$ in a $50 \mu \mathrm{l}$ volume (final ethanol dose from vehicle solution was $<0.2 \mathrm{~g} / \mathrm{kg}$ ). Mice were treated once per day for $3 \mathrm{~d}$, with the final dose given $1 \mathrm{~h}$ before death. For E2 treatment, $0.2 \mu \mathrm{g}$ E2 in $50 \mu \mathrm{l}$ volume $(\sim 10 \mu \mathrm{g} / \mathrm{kg})$ was injected subcutaneously on the first $2 \mathrm{~d}$ and $1 \mu \mathrm{g}$ of $\mathrm{E} 2 \mathrm{in}$ $50 \mu \mathrm{l}$ volume ( $\sim 50 \mu \mathrm{g} / \mathrm{kg})$ on the third day, $1 \mathrm{~h}$ before death. These doses and timing of E2 treatment were chosen because they result in E2 plasma levels similar to proestrus (Vandegrift et al., 2017), when E2 levels peak. The concentrations of PPT and DPN were chosen to balance receptor selectivity with occupancy (Sepehr et al., 2012; Hilderbrand and Lasek, 2018).

Extracellular recordings and in vitro drug treatments. VTA-containing brain slices were prepared for extracellular electrophysiology as previously described (Brodie et al., 1999; Dutton et al., 2017). Recording electrodes were placed in the VTA under visual control. Only those neurons that were located within the lateral VTA and conformed to the criteria for DA neurons established in the literature and in this laboratory (Brodie et al., 1988; Lacey et al., 1989; Mueller and Brodie, 1989) were studied. Not all VTA neurons in this study were characterized pharmacologically with baclofen as DA-containing neurons (Margolis et al., 2006, 2012), but all of the neurons conforming to these electrophysiological criteria that have been tested with baclofen $(0.1-1 \mu \mathrm{M})$ in our laboratory have been inhibited; sensitivity to inhibition by baclofen is a property of DA VTA neurons, but not GABAergic VTA neurons (Margolis et al., 2012). Spontaneous spike frequency (firing rate) was recorded, and changes in firing rate were determined. A calibrated infusion pump was used to apply ethanol and the mGluR1 antagonist JNJ 16259685 to the aCSF from stock solutions prepared at 100 $1000 \times$ the final concentration. JNJ 16259685 was prepared in $100 \%$ DMSO, and the final concentration in the bath was $0.2 \mu \mathrm{m}$. The ER $\beta$ antagonist PHTPP (4-[2-phenyl-5,7-bis(trifluoromethyl)pyrazolo[1,5-a]pyrimidin-3-yl]phenol, Tocris Bioscience) and ER $\alpha$ antagonist MPP (1,3-bis(4-hydroxyphenyl)-4-methyl-5-[4-(2-piperidinylethoxy)phenol]- $1 H$-pyrazole dihydrochloride, Tocris Bioscience) were administered via the micropipette by adding the drug to the microelectrode filling solution. Drugs were added to the $0.9 \% \mathrm{NaCl}$ microelectrode filling solution, and time was permitted for the antagonists to diffuse from the recording pipette into the extracellular space around the neuron being recorded.

Viral vectors. Lentiviruses expressing shRNAs targeting Esr1 (shEsr1-1785, GGCATGGAGCATCTCTACA), Esr2 (shEsr2-1089, GTACGAAGACAGAGAAGTG), or a sequence not predicted to target 


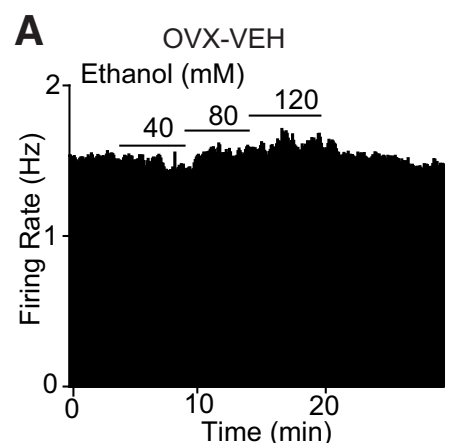

B

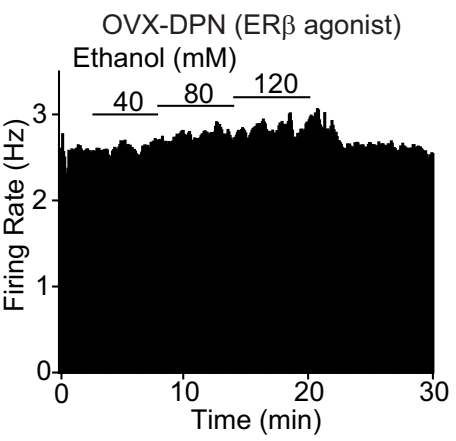

C OVX-PPT (ER $\alpha$ agonist)
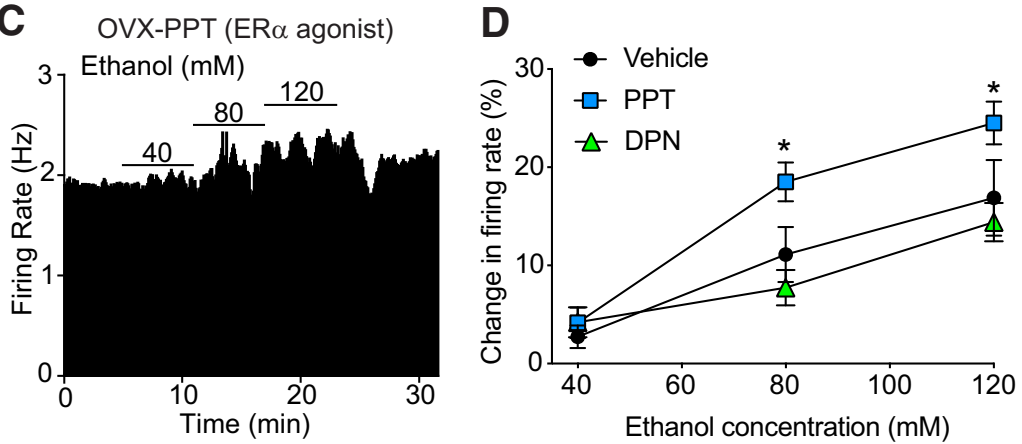

Figure 2. Activation of ER $\alpha$ enhances ethanol sensitivity of VTA neurons. Extracellular recordings were obtained from VTA neurons in OVX mice treated systemically with an $\mathrm{ER} \beta$ agonist (DPN), ER $\alpha$ agonist (PPT), or vehicle (VEH). A-C, Rate meter graphs represent response to 40-120 mM ethanol of a representative neuron from an OVX mouse treated with VEH $(\boldsymbol{A})$, DPN (B), or PPT (C). D, Ethanol concentration-response graph $(40,80$, and $120 \mathrm{~mm})$. Neurons from 0VX mice treated with PPT $(n=10)$, but not DPN $(n=10)$, had enhanced excitation by ethanol compared with VEH-treated mice $(n=11)$. ${ }^{*} p<0.05$ (post hoc Holm-Sidak's multiple comparisons test).

any gene in the mouse genome (shScr) were generated from the pLL3.7 vector (Lasek et al., 2007). The Esr1-targeting sequence was obtained from Musatov et al. (2006), who demonstrated an $80 \%$ reduction in ER $\alpha$ protein and transcript in vitro and complete lack of $\mathrm{ER} \alpha$ protein in the hypothalamus after AAV injection. We previously validated the shEsr1 lentiviral construct used in this study in vitro in Satta et al. (2018b) and observed a 70\% knockdown of Esr1 transcript. The lentiviral construct expressing shEsr2 was tested for the ability to knock down Esr2 in Neuro2a cells and reduced Esr 2 transcript levels by $94.3 \pm 1.5 \%$. We were unable to validate the shEsr2 construct in vivo because transcript levels in the VTA are below the limit of detection by qPCR (Cq values $~ 34$ ) and because there are no commercially available antibodies specific to mouse ER $\beta$ (Snyder et al., 2010). The pLL3.7 vector included a CMV-enhanced EGFP reporter cassette for infection site verification after the completion of behavioral testing. Lentiviral plasmids are available from Addgene (\#120720 and \#120722). The AAV-expressing Cre recombinase from the rat TH promoter (AAV.rTH.PI.Cre.SV40) was a gift from James M. Wilson (Addgene, viral prep \#107788-AAV9, RRID:Addgene_107788).

Stereotaxic injection of virus into the VTA. Gonadally intact, female mice were anesthetized with a solution of ketamine and xylazine and placed in a digital stereotaxic alignment apparatus. After bregma alignment and skull leveling, $0.28 \mathrm{~mm}$ diameter holes were drilled bilaterally (AP: -3.2 , ML: \pm 0.5 ) for virus microinjection. Virus was delivered to the VTA (DV: -4.7 ) at a rate of $0.2 \mu \mathrm{l} / \mathrm{min}$ for a total injection volume of $1 \mu \mathrm{l}$ or $0.5 \mu \mathrm{l} /$ hemisphere for lentivirus or AAV, respectively. After surgery, mice were maintained on a normal $12 \mathrm{~h}$ light/dark cycle for 1 week. Mice were then either kept in normal housing conditions for an additional 3 weeks before electrophysiology (AAV) or transferred to a reversed light/dark cycle room (lights off at 10:00 A.M. and on at 10:00 P.M.) and housed individually for 2 weeks to acclimate to the change in light/dark cycle before testing drinking (lentivirus).

Ethanol and sucrose drinking tests. The drinking in the dark procedure was used as a model of binge ethanol consumption because it allows mice to achieve blood ethanol levels exceeding $80 \mathrm{mg} / \mathrm{dl}$ in a $2-4 \mathrm{~h}$ period (Rhodes et al., 2007; Dutton et al., 2017), which is defined as binge drinking by the National Institute on Alcohol Abuse and Alcoholism. For ethanol drinking, mice were given access to a single bottle of $20 \%$ ethanol, $3 \mathrm{~h}$ into the dark cycle for $2 \mathrm{~h}$ per day on Tuesday through Thursday and $4 \mathrm{~h}$ on Friday. Ethanol intake was measured on Friday at 2 and 4 $\mathrm{h}$ into the session. Blood was collected from the tail vein immediately after the $4 \mathrm{~h}$ session on Friday, and BECs were measured using a nicotinamide adenine dinucleotide-alcohol dehydrogenase enzymatic assay (Zapata et al., 2006). Two independent cohorts of mice were injected with lentiviruses and tested for ethanol drinking, and data were combined from both cohorts after excluding inaccurate or absent viral infections (shScr, $n=10$; shEsr1, $n=10$; shEsr2, $n=9$ ). For sucrose drinking, animals were presented with a solution of $2 \%$ sucrose in water instead of ethanol using the same drinking in the dark procedure as described for ethanol. Two independent cohorts of mice were injected with lentiviruses and tested for sucrose drinking and data combined from both cohorts (shScr, $n=11$; shEsr1, $n=10$; shEsr2, $n=8$ ). Viral infection in the VTA was confirmed for both cohorts, except the in the second shScr $(n=5)$ control group because of an error in tissue processing. However, the two shScr cohorts did not differ statistically in sucrose intake, and so the second cohort was included in the data analysis.

Experimental design and statistical analysis. Details on numbers and sex of animals used are indicated in the Results section for each experiment. Data are presented as the mean \pm SEM. Statistical comparisons were made using Student's $t$ test, one-way ANOVA, two-way ANOVA, or twoway repeated-measures ANOVA as indicated for each experiment in Results. Holm-Sidak's or Tukey's multiple comparisons tests were performed as indicated (Prism, GraphPad Software). A $p$ value of $<0.05$ was considered significant.

\section{Results}

$\mathrm{ER} \alpha$ and ER $\beta$ are expressed in DA neurons and non-DA cells in the mouse VTA

The ERs, $\mathrm{ER} \alpha$ and $\mathrm{ER} \beta$, have been detected in the VTA of mice and rats (Kritzer, 1997; Shughrue et al., 1997; Shughrue and Merchenthaler, 2001; Creutz and Kritzer, 2002; Mitra et al., 2003; Kritzer and Creutz, 2008; Milner et al., 2010). In rats, ER $\alpha$ and $\operatorname{ER} \beta$ immunoreactivity is observed in DA neurons and non-DA cells in the VTA as demonstrated by dual-labeling with an antibody to $\mathrm{TH}$, an enzyme in the DA biosynthetic pathway (Creutz and Kritzer, 2002; Kritzer and Creutz, 2008), but to our knowledge, this has not been investigated in mice. To confirm that $\operatorname{ER} \alpha$ and $\operatorname{ER} \beta$ are present in DA neurons in the mouse VTA, we performed fluorescent IHC on VTA sections of gonadally intact female mice. Transgenic mice expressing EGFP from the Esr 2 promoter (the gene encoding $\operatorname{ER} \beta$ ) were used as a reporter for $\mathrm{ER} \beta$ expression, and the GFP signal was amplified with an antibody to GFP. We first examined GFP and ER $\alpha$ localization and observed both $\mathrm{ER} \alpha$ and GFP immunoreactivity in the VTA (Fig. 1A-C). Nearly all of the cells expressing GFP were positive for $\operatorname{ER} \alpha$, but there were many cells that were positive for $\operatorname{ER} \alpha$ that did not express GFP. These results suggest that $\operatorname{ER} \alpha$ and $\operatorname{ER} \beta$ are coexpressed in some cells in the VTA, but that $\mathrm{ER} \alpha$ is expressed more widely than $\mathrm{ER} \beta$ in the VTA. GFP was visible in $\mathrm{TH}$-positive and $\mathrm{TH}$-negative cells, indicating that $\operatorname{ER} \beta$ is expressed in both DA and non-DA cells in the 
A $\operatorname{MPP}(E R \alpha$ antagonist $)$

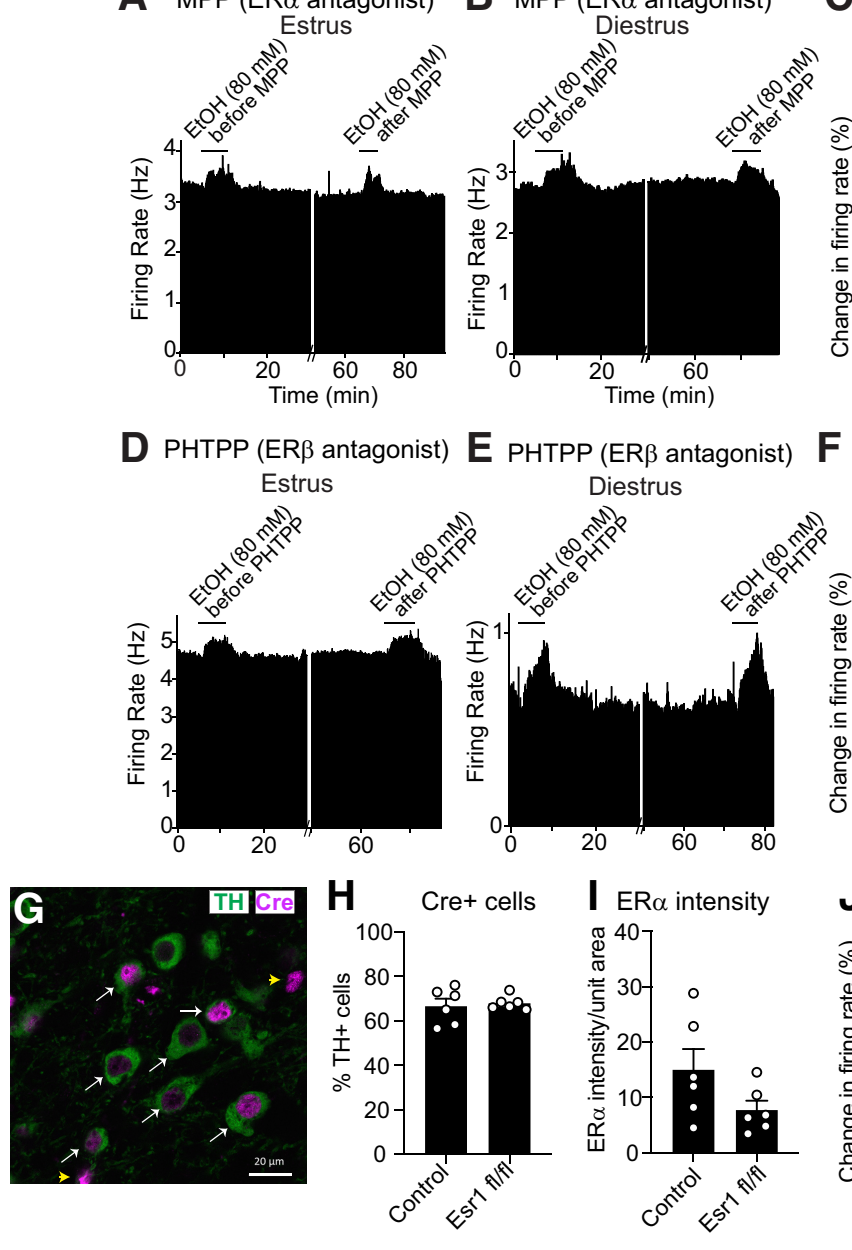

B $\operatorname{MPP}(E R \alpha$ antagonist $)$

C

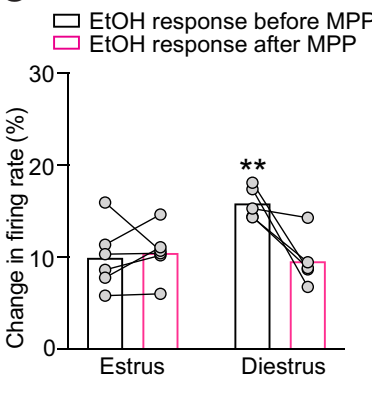

D PHTPP
Estrus
ER $\beta$ antagonist) E PHTPP (ER $\beta$ antagonist)

$\square$ EtOH response before PHTPP

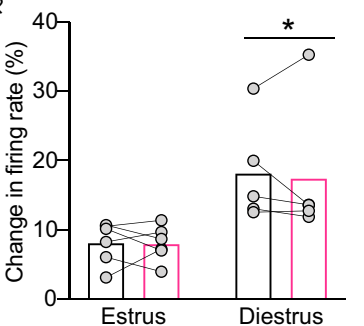

J $\rightarrow$ Control-Estrus $\quad-a-$ Esr1 fl/fl-Estrus

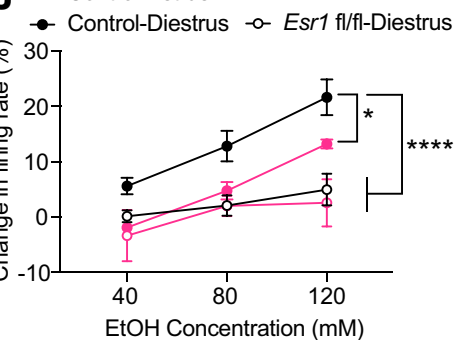

Figure 3. ER $\alpha$ regulates ethanol sensitivity of VTA neurons from mice in diestrus. $\boldsymbol{A}, \boldsymbol{B}$, Rate meter graphs represent the response of a representative neuron to $80 \mathrm{~mm}$ ethanol (EtoH) before and after treatment with the ER $\alpha$ antagonist MPP from mice in estrus $(\boldsymbol{A})$ and diestrus $(\boldsymbol{B})$. $\boldsymbol{C}$, Graph of neuronal responses to $80 \mathrm{~mm}$ EtOH from mice in estrus $(n=5)$ and diestrus $(n=6)$ before and after treatment of slices with MPP. The enhanced Et0H-induced excitation of neurons from mice in diestrus was decreased after treatment with MPP, whereas the EtOH responses of VTA neurons from mice in estrus are unchanged by MPP. ${ }^{* *} p<0.05$, comparing diestrus with estrus before MPP treatment and comparing responses in diestrus before and after MPP by post hoc Sidak's multiple comparisons test. $\boldsymbol{D}, \boldsymbol{E}$, Rate meter graphs represent the response of a representative neuron to $80 \mathrm{~mm} E \mathrm{EtOH}$ before and after treatment with the ER $\beta$ antagonist PHTPP from mice in estrus $(\boldsymbol{D})$ and diestrus $(\boldsymbol{E})$. $\boldsymbol{F}$, Graph of neuronal responses to $80 \mathrm{~mm}$ EtOH from mice in estrus $(n=6)$ and diestrus $(n=5)$ before and after treatment of slices with PHTPP. There was no change in EtOH excitation after PHTPP treatment, but there was a significant main effect of cycle phase. ${ }^{*} p<0.05$, main effect of cycle (two-way ANOVA). G, Representative image showing Cre recombinase expression in TH-expressing neurons in the VTA. Brain sections transduced with AAV9-Th-Cre virus were processed for fluorescent IHC with antibodies to Cre recombinase (magenta) and TH (green). White arrows indicate TH-positive and Cre-positive cells. Yellow arrowheads indicate 2 cells expressing Cre but not TH. Scale bar, $20 \mu \mathrm{m}$. $\boldsymbol{H}$, Graph of $\%$ of Cre-expressing cells that also express TH in control and Esr1 fl/fl mice ( $n=6$ mice, each mouse as the mean of 8 neurons). $I$, Graph of ER $\alpha$ immunoreactivity in TH-expressing cells in control and Esr1 fl/fl mice ( $n=6$ mice, each mouse as the mean of 8 neurons). J, Graph of neuronal responses to EtOH (40, 80, and $120 \mathrm{~mm}$ ) in control mice and Esr $1 \mathrm{fl} / \mathrm{fl}$ mice in estrus and diestrus. ${ }^{*} p<0.05 ;{ }^{* * *} p<0.0001$; Tukey's test after two-way repeated-measures ANOVA.

mouse VTA (Fig. 1G-I). Finally, we examined ER $\alpha$ and TH immunostaining in nontransgenic female C57BL/6J mice and observed that $\mathrm{ER} \alpha$ immunoreactivity was visible in both $\mathrm{TH}$ positive and TH-negative cells in the VTA (Fig. $1 D-F)$. Together, these results indicate that $\operatorname{ER} \alpha$ and $\operatorname{ER} \beta$ are expressed in DA neurons of the female mouse VTA.

\section{Baseline firing rates of female mouse VTA neurons}

A total of 95 VTA neurons from 59 mice were recorded. Specific numbers of neurons and mice for each experiment are described separately in Results for that experiment. The initial firing rates of the neurons ranged from 0.54 to $4.66 \mathrm{~Hz}$, and the mean firing rate was $1.92 \pm 0.11 \mathrm{~Hz}$. There was a significant difference in baseline firing rates between neurons from mice in diestrus and estrus, with a mean firing rate of $2.28 \pm 0.25 \mathrm{~Hz}$ during estrus and $1.71 \pm 0.18 \mathrm{~Hz}$ during diestrus $\left(t_{(33)}=1.89, p=0.034\right)$. There were no significant differences in baseline firing rates between neurons from OVX mice treated with VEH $(2.34 \pm 0.38 \mathrm{~Hz})$, PPT $(1.57 \pm 0.23 \mathrm{~Hz}), \mathrm{DPN}(1.97 \pm 0.33 \mathrm{~Hz})$, or $\mathrm{E} 2(1.85 \pm 0.27 \mathrm{~Hz}$; one-way ANOVA, $\left.F_{(2,25)}=1.45, p=0.24\right)$. There were also no significant differences in baseline firing among the groups in experiments using Esr1 fl/fl and control mice transduced with AAVexpressing Cre recombinase, with control-estrus $(2.89 \pm 0.52 \mathrm{~Hz})$, control-diestrus $(2.84 \pm 0.17 \mathrm{~Hz}), \operatorname{Esr} 1 \mathrm{fl} / \mathrm{fl}$-estrus $(2.82 \pm 0.66 \mathrm{~Hz})$, or Esr1 fl/fl-diestrus $\left(2.91 \pm 0.48 \mathrm{~Hz}\right.$; one-way ANOVA, $F_{(3,19)}=$ $0.0063, p=0.99$ ).

\section{Activation of ER $\alpha$ enhances ethanol sensitivity of VTA neurons}

We previously demonstrated that OVX mice treated with E2 exhibit enhanced ethanol-induced excitation of VTA neurons (Vandegrift et al., 2017). In order to determine which ER is 
A

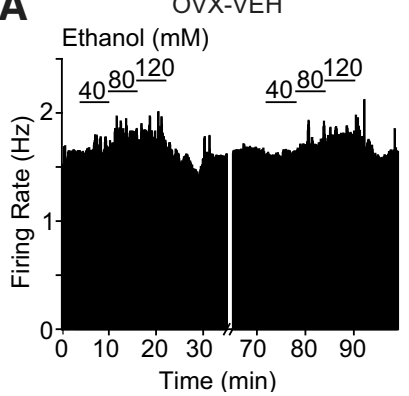

C

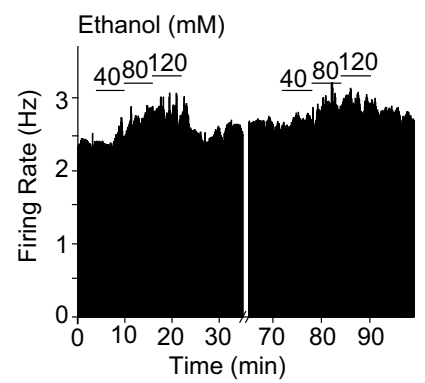

B

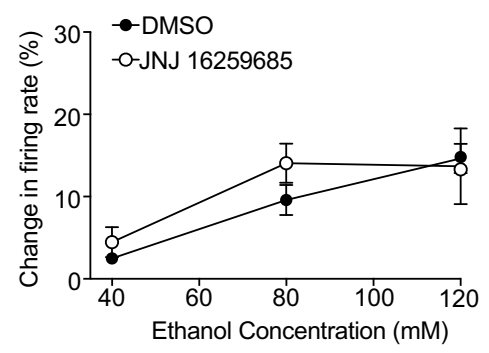

D

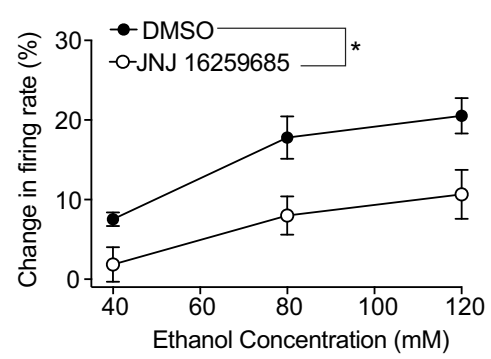

Figure 4. mGluR1 is required for the E2-induced enhancement of ethanol excitation. $\boldsymbol{A}$, Rate meter graph represents the response to 40-120 mm ethanol of a representative neuron from an OVX mouse treated with vehicle (VEH) before and after treatment with the mGluR1 antagonist JNJ 16259685. B, Ethanol concentration-response graph of neurons $(n=5)$ from OVX mice treated with VEH showing responses before (DMSO vehicle) and after slice treatment with JNJ 16259685. C, Rate meter graph represents the response to 40-120 mM ethanol of a representative neuron from an E2-treated OVX mouse before and after treatment with JNJ 16259685. D, Ethanol concentration-response graph of neurons $(n=6)$ from Ell-treated OVX mice before and after treatment of slices with JNJ 16259685. The ethanol excitation of neurons from E2treated OVX mice was significantly reduced after JNJ 16259685. ${ }^{*} p<0.05$, main effect of treatment (two-way repeatedmeasures ANOVA).

involved in enhancing ethanol sensitivity, we measured ethanolinduced excitation (40-120 mM) of VTA neurons from OVX mice treated with PPT (an ER $\alpha$-selective agonist), DPN (an $\operatorname{ER} \beta$-selective agonist), or VEH. VTA neurons from OVX mice treated with PPT had significantly higher ethanol-induced excitation compared with neurons from DPN- and VEH-treated mice (Fig. 2; VEH, $n=11$ cells from 4 mice; PPT, $n=10$ cells from 3 mice; DPN, $n=10$ cells from 4 mice; two-way repeatedmeasures ANOVA, ethanol concentration: $F_{(2,56)}=57.02$, $p<0.0001$; treatment: $F_{(2,28)}=4.05, p=0.028$; concentration $\times$ treatment interaction: $\left.F_{(4,56)}=3.06, p=0.024\right)$. In response to bath application of $80 \mathrm{~mm}$ ethanol, the firing rate of neurons from PPT-treated mice increased by $18.5 \pm 1.97 \%$. In comparison, the firing rate of neurons from DPN- and VEH-treated mice increased by $7.7 \pm 1.8 \%$ and $11.1 \pm 2.8 \%$, respectively. Post hoc Holm-Sidak's multiple comparisons test demonstrated a significant increase in ethanol-induced excitation in response to 80 mM ethanol from mice treated with PPT compared with VEH $(p=0.046)$ and DPN $(p=0.0044)$, and in response to $120 \mathrm{~mm}$ ethanol from mice treated with PPT compared with VEH $(p=0.038)$ and DPN $(p=0.0082)$. These results indicate that activation of $\operatorname{ER} \alpha$ enhances the response of VTA neurons to ethanol in OVX mice and suggests that the E2-induced increase in ethanol sensitivity is likely due to activation of $\operatorname{ER} \alpha$.

ER $\alpha$ regulates ethanol sensitivity of VTA neurons from mice in diestrus

VTA neurons from mice in diestrus are more sensitive to ethanol excitation compared with neurons from mice in estrus (Vandegrift et al., 2017). This enhancement of ethanolinduced excitation in diestrus is blocked by acute administration of the $\operatorname{ER} \alpha / \operatorname{ER} \beta$ antagonist, ICI 182780 , directly to the VTA slice (Vandegrift et al., 2017). To determine whether this effect results from blocking the activity of a specific ER, we administered MPP, an ER $\alpha$-selective antagonist, or PHTPP, an $\operatorname{ER} \beta$-selective antagonist, to VTA slices from mice in diestrus or estrus using the recording pipette. The response to $80 \mathrm{~mm}$ ethanol was tested before administration of the antagonist and again 70-80 min later, after the antagonist diffused from the recording pipette onto the cell of interest. The $\mathrm{ER} \alpha$ antagonist MPP decreased the excitatory response of VTA neurons to ethanol from mice in diestrus but had no effect on neurons from mice in estrus (Fig. $3 A-C$; diestrus, $n=5$ cells from 5 mice; estrus, $n=6$ cells from 4 mice; twoway repeated-measures ANOVA, time: $F_{(1,9)}$ $=7.46, p=0.023$; phase: $F_{(1,9)}=3.50, p=0.094$; time $\times$ phase interaction: $F_{(1,9)}=10.50$, $p=0.01$ ). Post hoc Holm-Sidak's multiple comparisons test demonstrated a significant difference in ethanol-induced excitation between estrus $(9.9 \pm 1.4 \%$ increase) and diestrus (15.9 $\pm 0.8 \%$ increase) before MPP treatment $(p=0.0054)$, consistent with our previous findings (Vandegrift et al., 2017). After administration of MPP, there was no longer a difference $(p=0.60)$ in ethanol-induced excitation between diestrus (9.6 $\pm 1.3 \%$ increase) and estrus ( $10.5 \pm 1.1 \%$ increase) because of a significant reduction in ethanol-induced excitation in neurons from mice in diestrus $(p=0.0058)$. These results suggest that $\mathrm{ER} \alpha$ acutely regulates ethanol sensitivity in the VTA in an estrous cycle phase-dependent manner.

In contrast to results obtained with the $\operatorname{ER} \alpha$ antagonist, the ER $\beta$ antagonist PHTPP had no effect on ethanol sensitivity of VTA neurons. As expected, there was a significant main effect of estrous cycle phase, indicating enhanced ethanol excitation in neurons from mice in diestrus compared with estrus (Fig. 3D-F; diestrus, $n=5$ cells from 4 mice; estrus, $n=6$ cells from 5 mice; two-way repeated-measures ANOVA, time: $F_{(1,9)}=0.18$, $p=0.68$; phase: $F_{(1,9)}=7.17, p=0.025$; time $\times$ phase interaction: $\left.F_{(1,9)}=0.088, p=0.77\right)$. Neurons from mice in estrus exhibited no increase in the response to ethanol, as ethanol increased firing by $8.0 \pm 1.2 \%$ and $7.9 \pm 1 \%$ before and after PHTPP delivery, respectively. Likewise, while neurons from mice in diestrus initially responded to $80 \mathrm{~mm}$ ethanol with an $18.1 \pm 3.3 \%$ increase in firing rate, after PHTPP delivery, these neurons responded similarly to ethanol with a $17.4 \pm 4.5 \%$ increase in firing rate. Together, these results indicate that $\operatorname{ER} \alpha$, but not $\operatorname{ER} \beta$, enhances the ethanol-induced excitation of VTA neurons in female mice during diestrus, when E2 levels are higher than in estrus.

Our results indicate that $\mathrm{ER} \alpha$ in the VTA is necessary for the increased ethanol sensitivity of VTA neurons. As demonstrated in Figure 1, ER $\alpha$ is expressed in DA and non-DA cells in the VTA and could conceivably act in non-DA cells to alter the excitation of DA neurons. To determine whether ER $\alpha$ expression in VTA DA neurons alters ethanol-induced excitation, we performed an experiment in which we transduced VTA neurons in 
homozygous floxed Esr1 (gene encoding $\mathrm{ER} \alpha, E s r 1 \mathrm{fl} / \mathrm{fl}$ ) mice with an AAV9 driving Cre recombinase expression from the $T h$ promoter to conditionally $\mathrm{KO}$ expression of $\mathrm{ER} \alpha$ in VTA DA neurons. Female C57BL/6 mice with nonfloxed Esr1 alleles were injected with the virus as controls. Immunostaining of brain sections with Cre and $\mathrm{TH}$ antibodies 4 weeks after virus infusion demonstrated that $\sim 70 \%$ of Cre-positive cells were immunoreactive for $\mathrm{TH}$ (Fig. $3 G$, $H$ ), indicating that the majority of cells expressing Cre were DA neurons. However, $\sim 30 \%$ of cells that expressed Cre did not have visible $\mathrm{TH}$ immunoreactivity. This is not unexpected, given that Th mRNA has been found to be expressed in cells that do not produce $\mathrm{TH}$ protein (Yamaguchi et al., 2015). We also quantified ER $\alpha$ protein levels in TH-positive cells in separate adjacent brain sections using immunofluorescent antibodies. Despite the fact that not all $\mathrm{TH}$ positive cells express $\mathrm{ER} \alpha$, and that we were unable to determine whether cells were also coexpressing Cre (due to limitations in the species of the available antibodies), we found that $\mathrm{ER} \alpha$ protein was reduced in THexpressing cells by $\sim 50 \%$ compared with control mice injected with AAV (Fig. 3I; $\left.t_{(10)}=1.78, p=0.106\right)$, demonstrating that Cre reduced expression of $\mathrm{ER} \alpha$. TH intensity did not differ between control and Esr1 fl/fl mice transduced with AAV (data not shown). We next measured ethanolinduced excitation of VTA neurons from control and Esr $1 \mathrm{fl} / \mathrm{fl}$ mice transduced with AAV that were in estrus or diestrus. Control mice in diestrus exhibited increased sensitivity to ethanol-induced excitation compared with all other groups (Fig. 3J; control-diestrus, 6 cells from 3 mice; control-estrus, 3 cells from 2 mice; Esr $1 \mathrm{fl} / \mathrm{fl}$-diestrus, 5 cells from 3 mice; Esr $1 \mathrm{fl} / \mathrm{fl}$-estrus, 6 cells from 3 mice; two-way repeated-measures ANOVA, ethanol concentration: $F_{(2,47)}=11.73, p<0.0001$; genotype-phase: $F_{(3,47)}$ $=13.33, p<0.0001$; interaction: $\left.F_{(6,47)}=1.117, p=0.367\right)$. Post hoc Tukey's multiple comparisons test was used to determine the difference between genotypes at specific phases. There were significant differences between control-diestrus and control-estrus $(p=0.021)$, control-diestrus and Esr1 fl/fl-diestrus $(p<0.0001)$, and control-diestrus and Esr $1 \mathrm{fl} / \mathrm{fl}$-estrus $(p<0.0001)$. These results strongly support the hypothesis that ER $\alpha$ acts in VTA DA neurons to regulate sensitivity to ethanol-induced excitation.

\section{mGluR1 is required for the E2-induced enhancement of} ethanol excitation

E2 rapidly activates membrane-bound ERs that couple to mGluRs in hippocampal (Huang and Woolley, 2012) and striatal (Grove-Strawser et al., 2010) neurons. We hypothesized that mGluR activation might be occurring in the VTA of mice after E2 treatment and thus contributing to the enhancement of ethanol-simulated firing. To test this, OVX mice were administered E2 or VEH, and the response to $40-120 \mathrm{~mm}$ ethanol was measured in VTA neurons before and after bath application of the mGluR1 antagonist, JNJ 16259685. JNJ 16259685 did not affect ethanol excitation of VTA neurons from OVX mice treated with
B Estrus
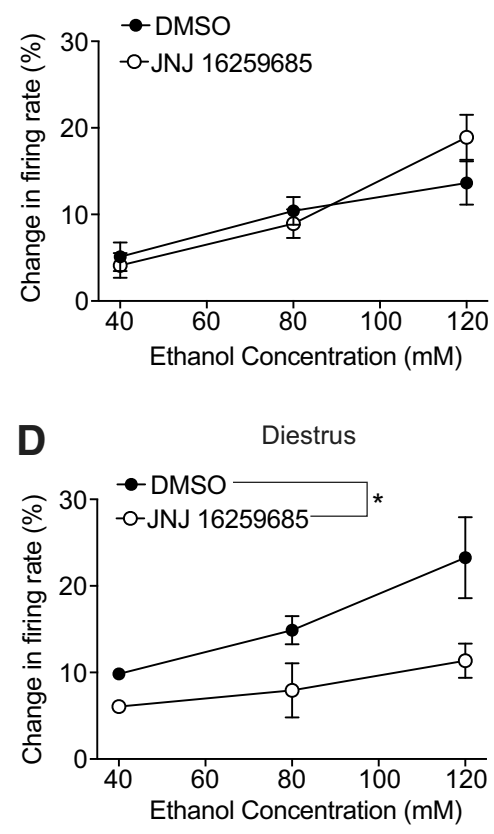

Figure 5. mGluR1 regulates ethanol sensitivity of VTA neurons from mice during diestrus. $\boldsymbol{A}$, Rate meter graph repre-

Diestrus

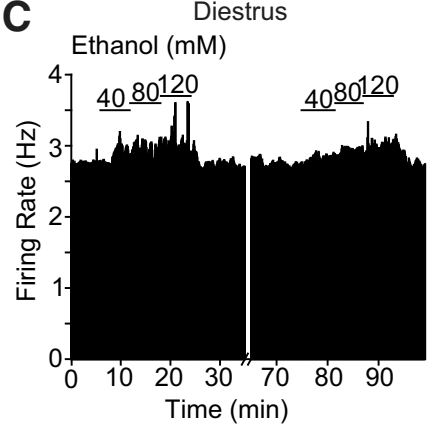

Estrus

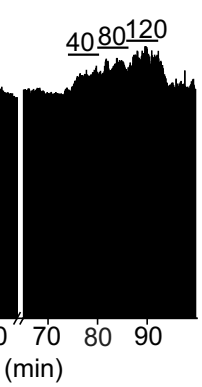

(1) 

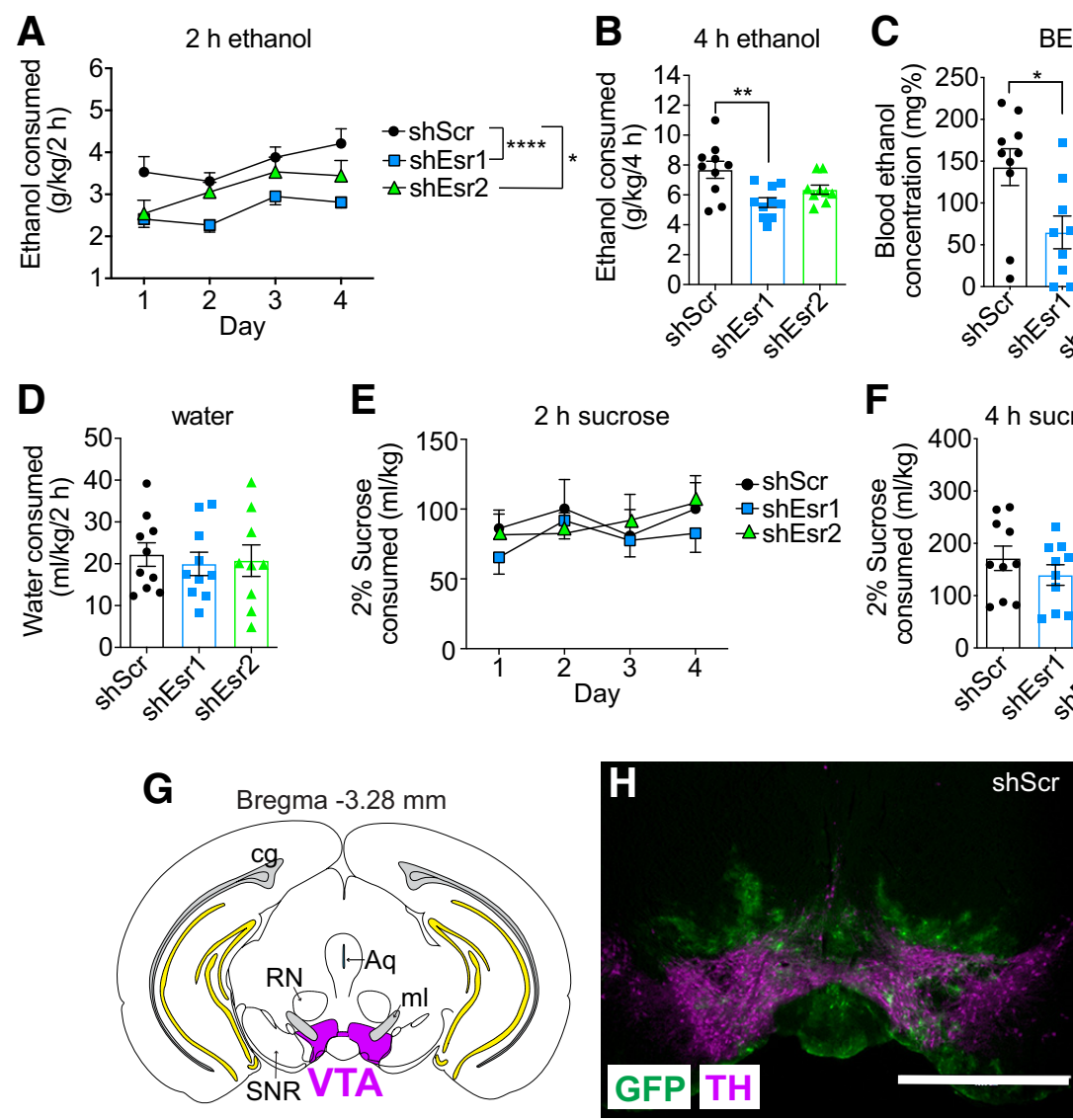

Figure 6. Intra-VTA knockdown of ERs reduces binge ethanol consumption in female mice. Gonadally intact female mice were injected with lentivirus expressing shScr (control, $n=10)$, shEsr1 $(n=10)$, or shEsr2 $(n=9)$ and tested for binge ethanol drinking in the drinking in the dark test. $\boldsymbol{A}$, Ethanol intake in $\mathrm{g} / \mathrm{kg}$ over $2 \mathrm{~h}$ on each day of drinking. ${ }^{*} p<0.05,{ }^{* * * *} p<0.0001$. $\boldsymbol{B}$ Ethanol intake in $\mathrm{g} / \mathrm{kg}$ during the final $4 \mathrm{~h}$ drinking session. ${ }^{* *} p<0.01$. C, BECs after the final $4 \mathrm{~h}$ drinking session. $\boldsymbol{D}$, Water intake during a $2 \mathrm{~h}$ session conducted $1 \mathrm{~d}$ before testing ethanol drinking. $\boldsymbol{E}$, Separate groups of mice were injected with lentivirus expressing shScr $(n=11)$, shEsr1 $(n=10)$, or shEsr2 $(n=8)$ and tested for consumption of $2 \%$ sucrose using the same procedure as was used for ethanol drinking. Shown is sucrose intake in $\mathrm{ml} / \mathrm{kg}$ over $2 \mathrm{~h}$ on each day of drinking. $\boldsymbol{F}$, Sucrose intake in $\mathrm{ml} / \mathrm{kg}$ during the final $4 \mathrm{~h}$ session. $\mathbf{G}$, Illustration of a coronal brain section showing injection site in the VTA (shaded magenta). For reference, yellow represents hippocampal structures and gray represents the cingulum. $\boldsymbol{H}$, Representative image of viral transduction in the VTA of mice. Green represents GFP. Magenta represents TH. Scale bar, $1 \mathrm{~mm}$. RN, Red nucleus; Aq, aqueduct; SNR, substantia nigra pars reticulata; $\mathrm{ml}$, medial lemniscus.

increase in firing in response to $80 \mathrm{~mm}$ ethanol before treatment with the mGluR1 antagonist and an $8.9 \pm 1.7 \%$ increase after treatment. In contrast, treatment with JNJ 16259685 decreased ethanol excitation of VTA neurons from females in diestrus (Fig. $5 C, D ; n=6$ cells from 6 mice, two-way repeated-measures ANOVA, treatment: $F_{(1,5)}=7.44, p=0.041$; ethanol concentration: $F_{(2,10)}=6.56, p=0.015$; treatment $\times$ concentration interaction: $\left.F_{(2,10)}=2.46, p=0.14\right)$. Neurons from mice in diestrus responded to $80 \mathrm{~mm}$ ethanol with a $14.9 \pm 1.6 \%$ increase in firing rate before treatment with the mGluR1 antagonist and a $7.9 \pm 3.1 \%$. increase in firing rate after treatment. These results indicate that mGluR1 activity is required for the increased sensitivity of VTA neurons to ethanol from mice in diestrus, similar to what we observed in mice treated with E2.

\section{Intra-VTA knockdown of ERs reduces binge ethanol consumption in female mice}

Female mice drink more alcohol than male mice in a binge drinking test, an effect that is attributed to E2 (Satta et al., 2018a). Our results demonstrating that $\operatorname{ER} \alpha$ activation increases the sensitivity of VTA neurons to ethanol suggest that ER $\alpha$
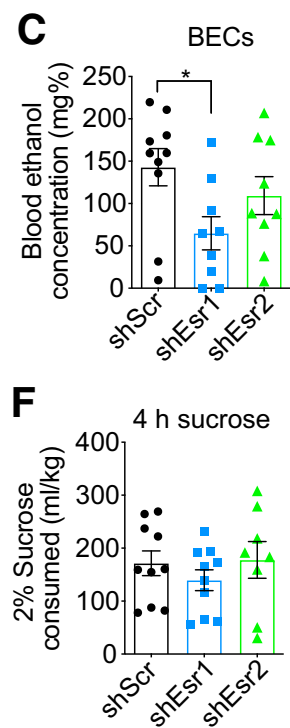

expression in the VTA might regulate binge drinking because of the critical role of the VTA in this behavior. To determine whether ERs in the VTA are important for alcohol drinking, we used shRNAs to locally knock down expression of Esrl (encoding ER $\alpha$ ) or Esr2 (encoding $\mathrm{ER} \beta$ ) in the VTA of gonadally intact female mice. Mice were injected with lentiviral vectors expressing shEsr1, shEsr2, or a shScr control and tested for binge ethanol drinking using the drinking in the dark test 3 weeks after injection. Two-way repeated-measures ANOVA revealed significant main effects of shRNA and time on ethanol intake during the $2 \mathrm{~h}$ drinking sessions, but no treatment $\times$ time interaction (Fig. 6A; shRNA: $F_{(2,26)}=13.10, p<0.0001$; time: $F_{(3,78)}$ $=6.02, p=0.001$; interaction: $F_{(6,78)}=$ $0.61, p=0.72$ ). Post hoc testing to identify differences in shRNA groups demonstrated that reducing Esr 1 expression in the VTA resulted in a $30 \%$ decrease $(p<0.0001)$ in $2 \mathrm{~h}$ ethanol intake over the $4 \mathrm{~d}$. Reducing Esr2 expression in the VTA also resulted a significant, albeit less pronounced, $16 \%$ decrease $(p=0.038)$ in $2 \mathrm{~h}$ ethanol intake over the $4 \mathrm{~d}$. Ethanol intake during the $4 \mathrm{~h}$ session on day 4 was attenuated by a reduction in ER levels in the VTA (Fig. $\left.6 B ; F_{(2,26)}=6.85, p=0.0041\right)$. Multiple comparisons testing revealed a significant $29 \%$ decrease in ethanol drinking in mice expressing shEsr $1 \quad(p=0.0030)$ and a nonsignificant $17 \%$ decrease in mice expressing shEsr2 $(p=0.097)$ in the VTA during the $4 \mathrm{~h}$ session. Consistent with reduced ethanol intake during the $4 \mathrm{~h}$ session, BECs were lower in mice with ER knockdown in the VTA (Fig. 6C; one-way ANOVA, $F_{(2,25)}=3.35, p=0.051$ ). This effect was driven by a $55 \%$ reduction in BECs in the shEsr 1 treatment group $(p=0.041)$, as BECs in the shEsr2 group were not significantly different from the shScr group (24\% reduction, $p=0.51)$. We also tested water intake $1 \mathrm{~d}$ before measuring ethanol consumption in the same mice and did not observe an effect of ER knockdown on water intake during a $2 \mathrm{~h}$ period (Fig. $6 D$ ), indicating that reducing ERs in the VTA does not affect general fluid intake. Viral transduction in the VTA was confirmed by dual immunofluorescent staining of brain sections using antibodies to TH and GFP (Fig. 6G,H). GFP was visible in the VTA and just dorsal to the VTA, extending slightly into the red nucleus; however, this region does not have detectable expression of ERs (Mitra et al., 2003). Selective knockdown of ERs in the VTA did not affect estrous cycles (data not shown), as mice continued to cycle normally throughout the duration of the experiment. Binge ethanol drinking also did not significantly vary during the estrous cycle, as reported previously (Satta et al., 2018a), nor was drinking altered only at specific phases of the estrous cycle by knockdown of ERs (data not shown). These 
results indicate that reducing levels of ERs in the VTA of female mice decreases binge-like drinking, with a stronger effect of ER $\alpha$ knockdown.

In order to determine whether the effects of intra-VTA ER knockdown on binge-like drinking were specific to ethanol or might extend to other rewarding substances, we performed the $4 \mathrm{~d}$ drinking in the dark test using $2 \%$ sucrose (instead of ethanol) with mice expressing shEsr1, shEsr2, or shScr in the VTA. There were no significant effects of shRNA, time, or an shRNA $\times$ time interaction for sucrose drinking during the $2 \mathrm{~h}$ sessions or during the final $4 \mathrm{~h}$ session (Fig. $6 E, F$ ), demonstrating that knockdown of ERs in the VTA of female mice does not affect consumption of all rewarding substances. Finally, to determine whether the effect of ER knockdown in the VTA is sex-specific, we injected lentiviruses expressing shScr, shEsrl, or shEsr2 into the VTA of male mice and tested them in the ethanol drinking in the dark test. Despite the fact that ERs are expressed in the VTA of males (Fig. 7) (Kritzer, 1997), knockdown of Esr1 or Esr2 did not alter ethanol drinking in male mice (Fig. 7). Fluorescent immunostaining with antibodies to GFP and ER $\alpha$ demonstrated a $54 \%$ reduction in $\mathrm{ER} \alpha$ levels in shEsr1 virus-infected cells. These results suggest a sexually dimorphic role for ERs in the VTA in ethanol binge drinking.

\section{Discussion}

The primary novel findings of this study are as follows: (1) activation of $\operatorname{ER} \alpha$ potentiates ethanol-induced excitation of VTA neurons; and (2) $\mathrm{ER} \alpha$, and to a lesser extent $\mathrm{ER} \beta$, in the VTA regulates binge-like ethanol drinking. We previously demonstrated that VTA neurons from mice in diestrus and E2-treated OVX mice are more sensitive to ethanol excitation than neurons from mice in estrus and VEH-treated OVX mice (Vandegrift et al., 2017). Multiple studies have found that E2-treated females consume more ethanol under various access conditions, including those that promote binge drinking (Ford et al., 2002a, 2004; Marinelli et al., 2003; Reid et al., 2003; Quirarte et al., 2007; Rajasingh et al., 2007; Satta et al., 2018a). Before this study, it was not known which ER(s) are responsible for these behavioral and neurophysiological effects.

Evidence that $\mathrm{ER} \alpha$ is responsible for the increased sensitivity of VTA neurons to ethanol in females is provided by our experiments in OVX mice treated with the selective $\mathrm{ER} \alpha$ agonist, PPT, and in brain slices from mice in diestrus treated with the $\mathrm{ER} \alpha$ antagonist, MPP. PPT treatment of OVX mice mimicked the effect of $\mathrm{E} 2$ treatment, indicating that activation of $\mathrm{ER} \alpha$ is most likely the mechanism by which E2 increased ethanol excitation of VTA neurons. We confirmed a role for ER $\alpha$ in the enhanced sensitivity to ethanol in gonadally intact mice in diestrus, showing that acute application of MPP decreased ethanol induced
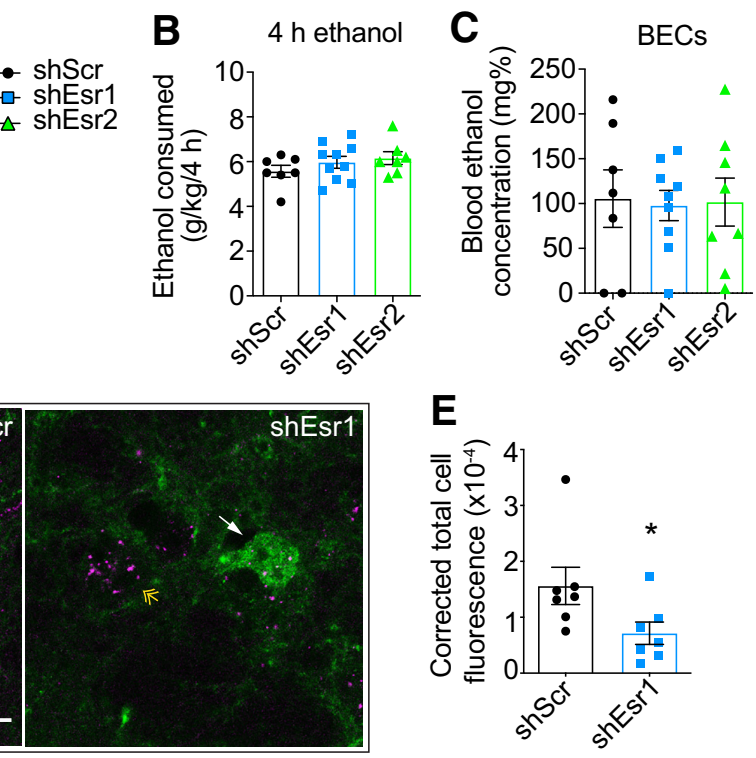

Figure 7. Intra-VTA knockdown of ERs does not affect binge ethanol consumption in male mice. Gonadally intact male mice were injected with lentivirus expressing shScr $(n=7)$, shEsr1 $(n=10)$, or shEsr2 $(n=7)$ and tested for binge ethanol drinking in the drinking in the dark test. $\boldsymbol{A}$, Ethanol intake in $\mathrm{g} / \mathrm{kg}$ over $2 \mathrm{~h}$ on each day of drinking. $\boldsymbol{B}$, Ethanol intake in $\mathrm{g} / \mathrm{kg}$ during the fession. C, BECs after the final $4 \mathrm{~h}$ drinking session. D, Representative images of GFP (green) and ER $\alpha$ (macell fluorescence (calculated as integrated density - area of selected cell $\times$ mean fluorescence of background readings). For each group, mean fluorescence from 7 cells (from 5 animals) is shown. ${ }^{*} p=0.051$.

excitation when E2 levels are rising (Nilsson et al., 2015). This result demonstrates that $\mathrm{ER} \alpha$ is important for the enhanced response to ethanol in a natural hormonal state, and not just in gonadectomized mice treated with E2. In contrast to the results obtained with $\mathrm{ER} \alpha$, pharmacological manipulation of $\mathrm{ER} \beta$ did not alter the potency of ethanol on VTA neurons, although ER $\beta$ is expressed in the VTA. Together, these data demonstrate an important role for E2 acting on ER $\alpha$ to increase ethanol sensitivity of VTA neurons.

It is likely that the ability of $\mathrm{ER} \alpha$ to enhance ethanol-induced excitation of VTA neurons is through direct action in DA neurons. We demonstrated that KO of ER $\alpha$ in VTA DA neurons using a genetic approach eliminated the enhanced sensitivity of these neurons to ethanol-induced excitation. One caveat of this experiment is that we observed some expression of Cre recombinase in neurons that were not immunoreactive for TH. These neurons could be expressing Th mRNA but not producing TH protein, which has been described by Yamaguchi et al. (2015). There is still a slight possibility that $\mathrm{ER} \alpha$ acts in non-DA cells in the VTA to alter ethanol-induced excitation of DA neurons because we found that $\mathrm{ER} \alpha$ is expressed in the soma of both DA and non-DA cells in the VTA. ER $\alpha$ is probably also present in neuronal terminals in the VTA, such as those from the medial preoptic area that project to the VTA and are known to regulate DA release in the NAc (Tobiansky et al., 2016; McHenry et al., 2017). Further investigation is needed to definitively conclude that $\mathrm{ER} \alpha$ regulates responses to ethanol through direct action in VTA DA neurons.

Our results suggest that activation of $\mathrm{ER} \alpha$ would increase ethanol-stimulated DA release in target regions, such as the NAc, which might contribute to enhanced rewarding and reinforcing effects of ethanol during high-estrogen states. Dazzi et al. 
(2007) demonstrated that ethanol increased DA release in the PFC of OVX rats treated with E2, but not in untreated OVX rats, and that treatment with the selective ER modulator clomifene prevented the ethanol-induced DA elevation. It remains to be determined whether treatment with an $\mathrm{ER} \alpha$-selective agonist or antagonist would alter ethanol-induced elevation of DA in regions, such as the NAc and PFC.

It is important to point out that basal firing rates of VTA neurons from mice in estrus were slightly higher than neurons from mice in diestrus. Other groups have shown that basal firing rate and bursting of VTA neurons are greater in estrus compared with diestrus (Zhang et al., 2008; Calipari et al., 2017). Supporting this observation, DA levels in the PFC and striatum of rats are also higher in estrus compared with diestrus (Xiao and Becker, 1994; Dazzi et al., 2007). Of note, acute treatment of VTA slices with ER antagonists did not decrease basal firing rates of VTA neurons. We also did not observe a difference in baseline firing rates in OVX mice treated with E2 compared with VEH. It is possible that the slightly higher firing rate observed in estrus compared with diestrus is not due to ongoing ER activity, but instead might result from actions of progesterone or progesterone-derived neurosteroids (Maguire et al., 2005).

The potential signaling mechanism(s) by which $\mathrm{ER} \alpha$ increased the ethanol sensitivity of VTA neurons was provided by our experiments using an mGluR1 antagonist, which decreased ethanol stimulation of neurons from mice in diestrus and of neurons from OVX mice treated with E2. These results indicate that mGluR1 is required for E2-mediated enhancement of ethanol-induced excitation of VTA neurons, and suggest that the effects of E2 may be due to rapid signaling at the cell membrane. ERs (both $\mathrm{ER} \alpha$ and $\mathrm{ER} \beta$ ) functionally couple to mGluRs in various brain regions, such as the hippocampus, striatum, and hypothalamus (Dewing et al., 2007; Grove-Strawser et al., 2010; Huang and Woolley, 2012; Oberlander and Woolley, 2016). ER $\alpha$ and mGluRs are associated in complexes at the cell membrane with caveolin proteins (Razandi et al., 2002; Boulware et al., 2007, 2013; Dewing et al., 2007; Meitzen et al., 2013; Tabatadze et al., 2015; Pastore et al., 2019). Our results support the possibility that a similar coupling of $\operatorname{ER} \alpha$ and mGluR1 occurs in the VTA of females and that this interaction is an important regulator of the sensitivity of VTA neurons to ethanol excitation. Determining whether there is a physical and functional interaction in the VTA between ER $\alpha$ and mGluR1 will be an important area for future research. In the hippocampus, E2 acts via mGluR1 to increase the production of the endocannabinoid anandamide, which functions in a retrograde manner to activate presynaptic cannabinoid (CB1) receptors, resulting in a suppression of presynaptic GABA release (Huang and Woolley, 2012). This mechanism could conceivably increase the sensitivity of VTA neurons to ethanol. Activation of $\mathrm{ER} \alpha / \mathrm{mGluR} 1$ by E2 in the hippocampus also increases phosphorylation of ERK, which is important for the enhancement of memory by E2 (Boulware et al., 2013).

ERs in the VTA of female mice are important for promoting binge-like alcohol drinking, as demonstrated by shRNA-mediated knockdown of $\operatorname{ER} \alpha$ and $\operatorname{ER} \beta$. We found a stronger decrease in ethanol drinking by reducing levels of $\operatorname{ER} \alpha$ compared with $\operatorname{ER} \beta$. It is possible that this is because $\operatorname{ER} \alpha$, and not $\operatorname{ER} \beta$, enhances excitation of VTA neurons by ethanol. We observed greater expression of $\mathrm{ER} \alpha$ versus $\mathrm{ER} \beta$ in the VTA, and it is also possible that the increased abundance of $\operatorname{ER} \alpha$ is responsible for its more prominent role in alcohol drinking. Reducing levels of $\operatorname{ER} \beta$ in the VTA modestly decreased binge-like ethanol drinking by females. Although ER $\beta$ does not alter the excitatory effect of ethanol on VTA neurons, it may play a role in the VTA in alcohol drinking by affecting the innate physiology of VTA DA neurons independently of ethanol stimulation, for instance, by altering the expression of various receptors or ion channels, or by altering the physiology of non-DA neurons that indirectly affect VTA DA neurons. Future experiments will examine how $\operatorname{ER} \beta$ acts to alter neuronal activity in the VTA.

One might have predicted from our electrophysiology results that: (1) ethanol consumption during diestrus would be higher than in estrus because of the greater response to ethanol during this phase, and (2) knockdown of $\operatorname{ER} \alpha$ in the VTA would only decrease ethanol drinking during diestrus, because the ER $\alpha$ antagonist MPP only altered ethanol-induced excitation of VTA DA neurons in diestrus and not in estrus. A close examination of our data indicated that there was no effect of estrous cycle phase on alcohol consumption, consistent with our previous findings and those of others (Roberts et al., 1998; Ford et al., 2002b; Priddy et al., 2017; Satta et al., 2018a). Knockdown of ER $\alpha$ in the VTA also did not decrease drinking only during diestrus; ethanol consumption was reduced by knockdown of $\mathrm{ER} \alpha$ regardless of estrous cycle phase. ERs in the VTA are important for promoting ethanol drinking in female mice, possibly through multiple mechanisms, including enhancing ethanol excitation of VTA neurons.

Interestingly, knockdown of ERs in the VTA of male mice did not affect binge-like ethanol drinking, despite the fact that males express $\mathrm{ER} \alpha$ and $\mathrm{ER} \beta$ in the VTA. Sex differences in the responses to E2 are not unprecedented. For example, E2 suppresses inhibitory neurotransmission in the hippocampus in females, but not in males, and this effect is mediated by ER $\alpha$ that are coupled to mGluR1 (Huang and Woolley, 2012) and the ability of E2 to increase the interaction of $\mathrm{ER} \alpha$ and mGluR1 in females but not in males (Tabatadze et al., 2015). Given our results demonstrating that $\mathrm{E} 2$ enhancement of ethanol excitation of VTA neurons requires mGluR1 activity, it is possible that an $\mathrm{ER} \alpha / \mathrm{mGluR} 1$ interaction is also operative in the VTA, resulting in a sex-specific role of ERs in the VTA on ethanol drinking. A more complete understanding of the E2-dependent signaling mechanism(s) in the VTA that drive binge ethanol drinking is an important area for future research and may lead to more effective treatments to reduce excessive drinking by women.

\section{References}

Agabio R, Campesi I, Pisanu C, Gessa GL, Franconi F (2016) Sex differences in substance use disorders: focus on side effects. Addict Biol 21:10301042.

Becker JB (1990a) Direct effect of 17 beta-estradiol on striatum: sex differences in dopamine release. Synapse 5:157-164.

Becker JB (1990b) Estrogen rapidly potentiates amphetamine-induced striatal dopamine release and rotational behavior during microdialysis. Neurosci Lett 118:169-171.

Boulware MI, Kordasiewicz H, Mermelstein PG (2007) Caveolin proteins are essential for distinct effects of membrane estrogen receptors in neurons. J Neurosci 27:9941-9950.

Boulware MI, Heisler JD, Frick KM (2013) The memory-enhancing effects of hippocampal estrogen receptor activation involve metabotropic glutamate receptor signaling. J Neurosci 33:15184-15194.

Brodie MS, Shefner SA, Dunwiddie TV (1988) Ethanol increases the firing of dopamine neurons of the ventral tegmental area in vitro. Alcohol Clin Exp Res 12:323.

Brodie MS, Pesold C, Appel SB (1999) Ethanol directly excites dopaminergic ventral tegmental area reward neurons. Alcohol Clin Exp Res 23:18481852 . 
Calipari ES, Juarez B, Morel C, Walker DM, Cahill ME, Ribeiro E, RomanOrtiz C, Ramakrishnan C, Deisseroth K, Han MH, Nestler EJ (2017) Dopaminergic dynamics underlying sex-specific cocaine reward. Nat Commun 8:13877.

Creutz LM, Kritzer MF (2002) Estrogen receptor-beta immunoreactivity in the midbrain of adult rats: regional, subregional, and cellular localization in the A10, A9, and A8 dopamine cell groups. J Comp Neurol 446:288300 .

Dazzi L, Seu E, Cherchi G, Barbieri PP, Matzeu A, Biggio G (2007) Estrous cycle-dependent changes in basal and ethanol-induced activity of cortical dopaminergic neurons in the rat. Neuropsychopharmacology 32:892901.

Dewing P, Boulware MI, Sinchak K, Christensen A, Mermelstein PG, Micevych P (2007) Membrane estrogen receptor-alpha interactions with metabotropic glutamate receptor 1a modulate female sexual receptivity in rats. J Neurosci 27:9294-9300.

Dutton JW 3rd, Chen H, You C, Brodie MS, Lasek AW (2017) Anaplastic lymphoma kinase regulates binge-like drinking and dopamine receptor sensitivity in the ventral tegmental area. Addict Biol 22:665-678.

Feng Y, Manka D, Wagner KU, Khan SA (2007) Estrogen receptor-alpha expression in the mammary epithelium is required for ductal and alveolar morphogenesis in mice. Proc Natl Acad Sci USA 104:14718-14723.

Ford MM, Eldridge JC, Samson HH (2002a) Ethanol consumption in the female Long-Evans rat: a modulatory role of estradiol. Alcohol 26:103113.

Ford MM, Eldridge JC, Samson HH (2002b) Microanalysis of ethanol selfadministration: estrous cycle phase-related changes in consumption patterns. Alcohol Clin Exp Res 26:635-643.

Ford MM, Eldridge JC, Samson HH (2004) Determination of an estradiol dose-response relationship in the modulation of ethanol intake. Alcohol Clin Exp Res 28:20-28.

Gonzales RA, Job MO, Doyon WM (2004) The role of mesolimbic dopamine in the development and maintenance of ethanol reinforcement. Pharmacol Ther 103:121-146.

Grant BF, Chou SP, Saha TD, Pickering RP, Kerridge BT, Ruan WJ, Huang B, Jung J, Zhang H, Fan A, Hasin DS (2017) Prevalence of 12-month alcohol use, high-risk drinking, and DSM-IV alcohol use disorder in the United States, 2001-2002 to 2012-2013: results From the National Epidemiologic Survey on Alcohol and Related Conditions. JAMA Psychiatry 74:911-923.

Grove-Strawser D, Boulware MI, Mermelstein PG (2010) Membrane estrogen receptors activate the metabotropic glutamate receptors mGluR5 and mGluR3 to bidirectionally regulate CREB phosphorylation in female rat striatal neurons. Neuroscience 170:1045-1055.

Hilderbrand ER, Lasek AW (2018) Estradiol enhances ethanol reward in female mice through activation of ERalpha and ERbeta. Horm Behav 98:159-164.

Huang GZ, Woolley CS (2012) Estradiol acutely suppresses inhibition in the hippocampus through a sex-specific endocannabinoid and mGluR-dependent mechanism. Neuron 74:801-808.

Kritzer MF (1997) Selective colocalization of immunoreactivity for intracellular gonadal hormone receptors and tyrosine hydroxylase in the ventral tegmental area, substantia nigra, and retrorubral fields in the rat. J Comp Neurol 379:247-260.

Kritzer MF, Creutz LM (2008) Region and sex differences in constituent dopamine neurons and immunoreactivity for intracellular estrogen and androgen receptors in mesocortical projections in rats. J Neurosci 28:9525-9535.

Lacey MG, Mercuri NB, North RA (1989) Two cell types in rat substantia nigra zona compacta distinguished by membrane properties and the actions of dopamine and opioids. J Neurosci 9:1233-1241.

Lasek AW, Janak PH, He L, Whistler JL, Heberlein U (2007) Downregulation of mu opioid receptor by RNA interference in the ventral tegmental area reduces ethanol consumption in mice. Genes Brain Behav 6:728-735.

Lovinger DM, Alvarez VA (2017) Alcohol and basal ganglia circuitry: animal models. Neuropharmacology 122:46-55.

Maguire JL, Stell BM, Rafizadeh M, Mody I (2005) Ovarian cycle-linked changes in $\mathrm{GABA}(\mathrm{A})$ receptors mediating tonic inhibition alter seizure susceptibility and anxiety. Nat Neurosci 8:797-804.

Margolis EB, Lock H, Hjelmstad GO, Fields HL (2006) The ventral tegmental area revisited: is there an electrophysiological marker for dopaminergic neurons? J Physiol 577:907-924.
Margolis EB, Toy B, Himmels P, Morales M, Fields HL (2012) Identification of rat ventral tegmental area GABAergic neurons. PLoS One 7:e42365.

Marinelli PW, Quirion R, Gianoulakis C (2003) Estradiol valerate and alcohol intake: a comparison between Wistar and Lewis rats and the putative role of endorphins. Behav Brain Res 139:59-67.

Martel MM, Eisenlohr-Moul T, Roberts B (2017) Interactive effects of ovarian steroid hormones on alcohol use and binge drinking across the menstrual cycle. J Abnorm Psychol 126:1104-1113.

Martin CA, Mainous AG 3rd, Curry T, Martin D (1999) Alcohol use in adolescent females: correlates with estradiol and testosterone. Am J Addict 8:9-14.

McHenry JA, Otis JM, Rossi MA, Robinson JE, Kosyk O, Miller NW, McElligott ZA, Budygin EA, Rubinow DR, Stuber GD (2017) Hormonal gain control of a medial preoptic area social reward circuit. Nat Neurosci 20:449-458.

Meitzen J, Luoma JI, Boulware MI, Hedges VL, Peterson BM, Tuomela K, Britson KA, Mermelstein PG (2013) Palmitoylation of estrogen receptors is essential for neuronal membrane signaling. Endocrinology 154:42934304.

Milner TA, Thompson LI, Wang G, Kievits JA, Martin E, Zhou P, McEwen BS, Pfaff DW, Waters EM (2010) Distribution of estrogen receptor beta containing cells in the brains of bacterial artificial chromosome transgenic mice. Brain Res 1351:74-96.

Mitra SW, Hoskin E, Yudkovitz J, Pear L, Wilkinson HA, Hayashi S, Pfaff DW, Ogawa S, Rohrer SP, Schaeffer JM, McEwen BS, Alves SE (2003) Immunolocalization of estrogen receptor beta in the mouse brain: comparison with estrogen receptor alpha. Endocrinology 144:2055-2067.

Mueller AL, Brodie MS (1989) Intracellular recording from putative dopamine-containing neurons in the ventral tegmental area of Tsai in a brain slice preparation. J Neurosci Methods 28:15-22.

Musatov S, Chen W, Pfaff DW, Kaplitt MG, Ogawa S (2006) RNAi-mediated silencing of estrogen receptor $\{$ alpha\} in the ventromedial nucleus of hypothalamus abolishes female sexual behaviors. Proc Natl Acad Sci USA 103:10456-10460.

Muti P, Trevisan M, Micheli A, Krogh V, Bolelli G, Sciajno R, Schunemann HJ, Berrino F (1998) Alcohol consumption and total estradiol in premenopausal women. Cancer Epidemiol Biomarkers Prev 7:189-193.

Nelson JF, Felicio LS, Randall PK, Sims C, Finch CE (1982) A longitudinal study of estrous cyclicity in aging C57BL/6J mice: I. Cycle frequency, length and vaginal cytology. Biol Reprod 27:327-339.

Nilsson ME, Vandenput L, Tivesten A, Norlen AK, Lagerquist MK, Windahl SH, Borjesson AE, Farman HH, Poutanen M, Benrick A, Maliqueo M, Stener-Victorin E, Ryberg H, Ohlsson C (2015) Measurement of a comprehensive sex steroid profile in rodent serum by high-sensitive gas chromatography-tandem mass spectrometry. Endocrinology 156:2492-2502.

Oberlander JG, Woolley CS (2016) 17beta-Estradiol acutely potentiates glutamatergic synaptic transmission in the hippocampus through distinct mechanisms in males and females. J Neurosci 36:2677-2690.

Pastore MB, Landeros RV, Chen DB, Magness RR (2019) Structural analysis of estrogen receptors: interaction between estrogen receptors and cav-1 within the caveolae. Biol Reprod 100:495-504.

Priddy BM, Carmack SA, Thomas LC, Vendruscolo JC, Koob GF, Vendruscolo LF (2017) Sex, strain, and estrous cycle influences on alcohol drinking in rats. Pharmacol Biochem Behav 152:61-67.

Quirarte GL, Reid LD, de la Teja IS, Reid ML, Sánchez MA, Díaz-Trujillo A, Aguilar-Vazquez A, Prado-Alcalá RA (2007) Estradiol valerate and alcohol intake: dose-response assessments. BMC Pharmacol 7:3.

Rajasingh J, Bord E, Qin G, Ii M, Silver M, Hamada H, Ahluwalia D, Goukassian D, Zhu Y, Losordo DW, Kishore R (2007) Enhanced voluntary alcohol consumption after estrogen supplementation negates estrogen-mediated vascular repair in ovariectomized mice. Endocrinology 148:3618-3624.

Razandi M, Oh P, Pedram A, Schnitzer J, Levin ER (2002) ERs associate with and regulate the production of caveolin: implications for signaling and cellular actions. Mol Endocrinol 16:100-115.

Reid ML, Hubbell CL, Reid LD (2003) A pharmacological dose of estradiol can enhance appetites for alcoholic beverages. Pharmacol Biochem Behav 74:381-388.

Rhodes JS, Ford MM, Yu CH, Brown LL, Finn DA, Garland T Jr, Crabbe JC (2007) Mouse inbred strain differences in ethanol drinking to intoxication. Genes Brain Behav 6:1-18. 
Roberts AJ, Smith AD, Weiss F, Rivier C, Koob GF (1998) Estrous cycle effects on operant responding for ethanol in female rats. Alcohol Clin Exp Res 22:1564-1569.

Sacks JJ, Gonzales KR, Bouchery EE, Tomedi LE, Brewer RD (2015) 2010 national and state costs of excessive alcohol consumption. Am J Prev Med 49:e73-e79.

Satta R, Hilderbrand ER, Lasek AW (2018a) Ovarian hormones contribute to high levels of binge-like drinking by female mice. Alcohol Clin Exp Res 42:286-294.

Satta R, Certa B, He D, Lasek AW (2018b) Estrogen receptor beta in the nucleus accumbens regulates the rewarding properties of cocaine in female mice. Int J Neuropsychopharmacol 21:382-392.

Sepehr E, Lebl-Rinnova M, Mann MK, Pisani SL, Churchwell MI, Korol DL, Katzenellenbogen JA, Doerge DR (2012) Pharmacokinetics of the estrogen receptor subtype-selective ligands, PPT and DPN: quantification using UPLC-ES/MS/MS. J Pharm Biomed Anal 71:119-126.

Shughrue PJ, Merchenthaler I (2001) Distribution of estrogen receptor beta immunoreactivity in the rat central nervous system. J Comp Neurol 436:64-81.

Shughrue PJ, Lane MV, Merchenthaler I (1997) Comparative distribution of estrogen receptor-alpha and -beta mRNA in the rat central nervous system. J Comp Neurol 388:507-525.

Snyder MA, Smejkalova T, Forlano PM, Woolley CS (2010) Multiple ERbeta antisera label in ERbeta knockout and null mouse tissues. J Neurosci Methods 188:226-234.

Stahre M, Roeber J, Kanny D, Brewer RD, Zhang X (2014) Contribution of excessive alcohol consumption to deaths and years of potential life lost in the United States. Prev Chronic Dis 11:E109.

Szabo G (2018) Women and alcoholic liver disease: warning of a silent danger. Nat Rev Gastroenterol Hepatol 15:253-254.

Tabatadze N, Huang G, May RM, Jain A, Woolley CS (2015) Sex differences in molecular signaling at inhibitory synapses in the hippocampus. J Neurosci 35:11252-11265.

Thompson TL, Moss RL (1994) Estrogen regulation of dopamine release in the nucleus accumbens: genomic- and nongenomic-mediated effects. J Neurochem 62:1750-1756.
Tobiansky DJ, Will RG, Lominac KD, Turner JM, Hattori T, Krishnan K, Martz JR, Nutsch VL, Dominguez JM (2016) Estradiol in the preoptic area regulates the dopaminergic response to cocaine in the nucleus accumbens. Neuropsychopharmacology 41:1897-1906.

Tonn Eisinger KR, Gross KS, Head BP, Mermelstein PG (2018) Interactions between estrogen receptors and metabotropic glutamate receptors and their impact on drug addiction in females. Horm Behav 104:130-137.

Vandegrift BJ, You C, Satta R, Brodie MS, Lasek AW (2017) Estradiol increases the sensitivity of ventral tegmental area dopamine neurons to dopamine and ethanol. PLoS One 12:e0187698.

Wen XJ, Kanny D, Thompson WW, Okoro CA, Town M, Balluz LS (2012) Binge drinking intensity and health-related quality of life among US adult binge drinkers. Prev Chronic Dis 9:E86.

White AJ, DeRoo LA, Weinberg CR, Sandler DP (2017) Lifetime alcohol intake, binge drinking behaviors, and breast cancer risk. Am J Epidemiol 186:541-549.

Xiao L, Becker JB (1994) Quantitative microdialysis determination of extracellular striatal dopamine concentration in male and female rats: effects of estrous cycle and gonadectomy. Neurosci Lett 180:155-158.

Yamaguchi T, Qi J, Wang HL, Zhang S, Morales M (2015) Glutamatergic and dopaminergic neurons in the mouse ventral tegmental area. Eur J Neurosci 41:760-772.

Yoest KE, Quigley JA, Becker JB (2018a) Rapid effects of ovarian hormones in dorsal striatum and nucleus accumbens. Horm Behav 104:119-129.

Yoest KE, Cummings JA, Becker JB (2018b) Oestradiol influences on dopamine release from the nucleus accumbens shell: sex differences and the role of selective oestradiol receptor subtypes. Br J Pharmacol 176:41364148.

Zapata A, Gonzales RA, Shippenberg TS (2006) Repeated ethanol intoxication induces behavioral sensitization in the absence of a sensitized accumbens dopamine response in C57BL/6J and DBA/2J mice. Neuropsychopharmacology 31:396-405.

Zhang D, Yang S, Yang C, Jin G, Zhen X (2008) Estrogen regulates responses of dopamine neurons in the ventral tegmental area to cocaine. Psychopharmacology (Berl) 199:625-635. 